Article

\title{
Empowering Leadership, Risk-Taking Behavior, and Employees' Commitment to Organizational Change: The Mediated Moderating Role of Task Complexity
}

\author{
Ki Baek Jung ${ }^{1}$, Seung-Wan Kang ${ }^{2, * \mathbb{C}}$ and Suk Bong Choi ${ }^{1, * \mathbb{D}}$ \\ College of Global Business, Korea University, 2511 Sejong-ro, Sejong City 30019, Korea; jkb7528@korea.ac.kr \\ 2 College of Business, Gachon University, Seongnam 13120, Korea \\ * Correspondence: global7@gachon.ac.kr (S.-W.K.); sukchoi@korea.ac.kr (S.B.C.)
}

Received: 14 February 2020; Accepted: 15 March 2020; Published: 17 March 2020

check for updates

\begin{abstract}
Successful organizational change is an important factor for maintaining sustainable competitive advantage and growth in today's rapidly changing business environment. The aim of this study is to investigate the relationship between empowering leadership and the commitment to organizational change of Korean employees and also examine whether risk-taking behavior mediates the above relationship. Moreover, we attempt to address the moderating role and mediated moderating role of task complexity in the relationship between risk-taking behavior and commitment to organizational change. The main hypotheses were tested using a cross-sectional design, with questionnaires administered to 275 employees working in Korean firms. The results of the empirical analysis revealed that empowering leadership was positively related to commitment to organizational change. The results also showed that risk-taking behavior positively mediated the relationship between empowering leadership and employees' commitment to organizational change. More importantly, we found that the indirect effect of empowering leadership on commitment to organizational change via risk-taking behavior was stronger when task complexity was high. Uncovering the relationship between empowering leadership and employees' commitment to organizational change through the mediating role of risk-taking behavior and the mediated moderating role of task complexity has useful theoretical and practical implications. The limitations of the study are discussed along with suggestions for future research.
\end{abstract}

Keywords: empowering leadership; risk-taking behavior; commitment to organizational change; task complexity; mediated moderation model

\section{Introduction}

It is important for firms to recognize the necessity of organizational change and proactively cope with environmental changes to secure sustainable competitive advantage and survive in today's business environment. Due to this rapidly changing business environment and the continuous challenges facing organizations, the interest of management scholars, managers, and policy-makers in sustainability has increased [1]. Employee attitudes and behaviors in relation to organizational change are important factors in the process of organizational change [2], which ultimately affects the sustainable growth of organizations. However, employees tend to feel threatened by change and may believe that it is not necessary [3]. Employees can be cynical and resist organizational change because they believe change threatens their stability and brings about an uncertain future [2]. Employees who are resistant to change respond by leaving the organization and this has a negative impact on organizational development and success [4]. Organizational change is driven by members, 
whose attitudes and involvement in the process are important factors for change management and the maintenance of sustainable competitive advantage [5]. Corporate leaders need to foster employees' views and attitudes towards organizational change. Employees of an organization in an uncertain business environment are increasingly required to drive change and actively perform their work [6]. Moreover, employees should be aware of the need for change for the development of the organization and help drive such change.

Meanwhile, commitment to organizational change is a key factor in gaining the support of employees in the process of organizational change [7]. If organizational change is a success, it is important that employees do not have negative perceptions about it. Moreover, success depends on employees having a positive attitude towards organizational change and getting involved in the process of change. Nevertheless, the research area of commitment to organizational change and its antecedents are not adequate [8]. Organizational change is essential for the sustainable growth of a company, but there are very few successful cases of organizational change, as $70 \%$ of the cases result in failure [9]. This high failure rate is due to the fact that change is promoted at an organizational level without focusing on the individual characteristics of the employees $[10,11]$. Thus, organizational change should begin with the employees of the organization. As such, the environment and the role of the leaders should be considered for maximizing individuals' positive attitude and behavior towards organizational change.

Leadership has a significant effect on attitudes, behaviors, and various levels of performance [12,13], including the sustainability of organizations [14]. Recent studies on leadership have discussed sustainable leadership, which focuses on a leaders' attitude and behavior towards connecting organizations to innovation and systematic change as a response to the business environment, society, business ethics, and corporate responsibility [14-16]. The sustainable style of leadership is required to address the rapidly changing business environment and promote proactive actions of employees for organizational changes. In this paper, we focus on empowering leadership as a type of sustainable leadership for effecting organizational change [17]. In empowering leadership, leaders delegate authority to their employees and increase motivation by giving them more responsibility and autonomy in their work [18,19], thereby increasing the sustainability of organizations. Previous studies suggest that empowering leadership has a positive impact on work-related outcomes [20-22]. Empowered employees are more motivated, responsible, and proactive in managing and improving their work [23]. Employees are also more creative and innovative in their work by responding flexibly and quickly to changes in the organizational environment [24]. Previous studies have shown that empowering leadership has a positive effect on team performance and knowledge sharing [17], innovation [25], in-role behavior and extra-role behavior [26], creativity [27], task proficiency, and proactive behavior [28]. These studies have confirmed the positive influence of empowering leadership. Nevertheless, they have not focused much on uncovering the mechanism and conditions that maximize the positive effects of empowering leadership on employees' commitment to organizational change.

To fill this gap in the existing literature, we extend the current knowledge in the following ways. First, organizational change to adapt to environmental changes is linked to employee attitudes, such as commitment to organizational change and change-oriented behavior. To this end, this study considers empowering leadership as a sustainable and effective style of leadership in the contemporary business environment [17] and examines how empowering leadership affects commitment to organizational change in the organizational change process. Second, we examine the role of risk-taking behavior as a mediator in the relationship between empowering leadership and employees' commitment to organizational change. Risk-taking behavior is defined as the proactive behavior of individuals, taking potential risks for positive organizational outcome. However, it has a negative effect on their reputation and career when the outcome is negative [29]. Implementing organizational change may bring a high level of uncertainty and risk not only to the organization, but also to employees involved in the process [11]. By considering risk-taking behavior as a key mechanism underlying the relationship between empowering leadership and commitment to organizational change, we attempt to enrich our 
understanding of how empowering leadership enhances employees' commitment to change. Third, we try to further our understanding of the role of risk-taking in promoting employees' commitment to organizational change by demonstrating the direct and indirect moderating role of task complexity. Task complexity can be seen as a specific nature of a task that requires extensive and diverse knowledge and skills to complete that task [30]. Employees with complex tasks may have a more challenging, open-minded, and innovative attitude towards organizational change. Thus, this study assumes that the extent to which risk-taking behavior results in positive commitment towards organizational change may depend on the level of complexity of tasks. Therefore, we proposed task complexity as an important condition for the predicted relationship between risk-taking behavior and employees' commitment to organizational change.

In summary, the purpose of this study is fourfold: it analyzes (1) the relationship between empowering leadership and commitment to organizational change; (2) the mediating role of risk-taking behavior in this relationship; (3) the moderating role of task complexity in the relationship between risk-taking behavior and commitment to organizational change; and (4) the integrative model of mediated moderation, to help advance our knowledge regarding the role of empowering leadership in organizational change. Uncovering the underlying process and conditions through which empowering leadership promotes employees' commitment to organizational change has theoretical and practical implications.

The structure of this paper is as follows: we discuss the research issue and research purpose, followed by the core concepts and theoretical background centered on hypotheses. The survey procedures and measures are then addressed. After presenting statistical results, the main findings of our empirical analysis are discussed. In light of the findings, important theoretical and practical implications are presented.

\section{Theoretical Background and Hypotheses}

\subsection{Empowering Leadership and Commitment to Organizational Change}

Empowerment is defined as the process of instilling motivation and self-efficacy in employees to eliminate employee helplessness [31]. It is also defined as the process of motivating employees to have autonomy and pursue a sense of meaning in achieving their goals [32]. Empowerment can also be defined as a psychological process that extends and strengthens authority to promote motivation for cognitive elements such as meaning, competence, self-determination, and influence that employees perceive in their work [33]. In addition, empowerment involves empowering and instilling responsibility while considering employees' capabilities. There is extensive academic understanding of empowering leadership [19]. It is characterized by individual consideration [34], supportive leadership [35], and participatory leadership [36]. According to contingency theory, it is also characterized by coaching, participation, and delegation [37]. In this study, these characteristics of empowering leadership are considered to have a positive impact on work performance.

On the other hand, change can be perceived as a threat to current stability and imply an uncertain future. Therefore, employees may resist it [2]. Furthermore, opinions and suggestions on change can be perceived as challenging the current conditions and resistance to leaders, so employees often feel that it is not safe to pursue change [38] and perceive it as a risk. Nevertheless, change is essential for an organization to survive [39] and the acceptance of organizational change by its employees influences its success [40]. As such, recent research focuses on the emotional response of employees to organizational change [41,42]. Previous research emphasized the importance of commitment to organizational change, which is the active psychological response of employees to change. Commitment to organizational change is defined as a mindset that binds an individual to a course of action deemed necessary for the successful implementation of a change initiative [43]. According to Herscovitch and Meyer [43], there are three types of commitment to change: affective commitment, which supports organizational change based on trust and attachment to the organization; normative commitment, in which support 
to organizational change is considered a duty that arises from a sense of moral obligation; and continuance commitment, which is based on the fear of cost of resistance to change or failure to support it. According to previous research, commitment to organizational change can be viewed as a key element in promoting true change behavior of employees in the process of organizational change $[5,7,44]$. Thus, commitment to organizational change is essential for its successful implementation.

This study demonstrates that empowering leadership will have a positive effect on commitment to organizational change based on the following reasons. Empowering leadership delegates authority and autonomy to employees, allowing them to work with confidence, value their contributions, and make their work more meaningful [19]. Through participative decision-making of empowering leadership [45], employees gain a sense of control over their performance and feel psychological empowerment [19], which can increase organizational commitment [33,46]. Psychological empowerment is an important factor in organizational change, as it allows employees to have control over their work and influence the process of organizational change [33,47]. Psychologically empowered employees are encouraged by organization leaders to engage in the process of organizational change.

Employees are committed to organizational change when leaders demonstrate participatory, achievement-oriented leadership, which leads to high employee motivation and work autonomy and helps to build a good relationship with leaders [48]. Empowering leadership provides employees with a high level of autonomy and the ability to achieve high performance in their work and supports capability-building [49]. When leaders demonstrate empowering leadership by sharing information, having a good relationship with employees, and encouraging employee participation in the process of organizational change, employees will be committed to its achievement successfully.

On the other hand, readiness for change is necessary for successful organizational change [50]. Readiness for change is defined as a member's beliefs and attitude regarding the possibility of organizational change [51]. It is influenced by leadership [52] and participative decision-making processes [51,53]. In empowering leadership, leaders manage their organizations by delegating authority and autonomy to employees and engaging them in decision-making processes [20]. Leaders also share information with employees and engage in decision-making based on their interactions with their teams [18]. Therefore, participative decision-making, which is a characteristic of empowering leadership, reflects the opinions of employees in the process of organizational change and develops employees' awareness regarding the necessity and possibility of change, thus serving as an antecedent for their commitment to organizational change.

In addition, empowering leadership expresses confidence in its employees' high performance and competence [19], provides autonomy, and allows employees to decide how to perform their work [28]. As a result, employees will view changes in the organizational environment as learning opportunities and actively respond to them by raising their self-efficacy and confidence in their beliefs and capabilities. Previous studies have also shown that the antecedents influencing commitment to organizational change are trust and fairness [54], relationship with leaders and autonomy [48], and self-efficacy $[5,20]$. Thus, we hypothesize the following:

Hypothesis 1. Empowering leadership is positively related to employees' commitment to organizational change.

\subsection{Mediating Role of Risk-Taking Behavior}

Risk is defined as the probability of loss [55] or the degree of uncertainty, in which decisions may not be realized as intended [56]. Risk is inevitable in modern life and pervasive in various fields, such as the business environment, healthcare, and education [55]. Individuals produce different results depending on how they respond to risk. Risk-taking behavior refers to the behavior and willingness of individuals to openly undertake potential risks for a positive outcome in a situation where negative consequences are expected [29]. Thus, the manner of responding to risk and the degree of risk-taking behavior can affect organizational operations. According to Dewett [29], risk-taking behavior can 
change depending on the leadership style of the organization's leaders. We expect it to mediate the relationship between empowering leadership and commitment to organizational change for the following reasons.

Empowering leadership recognizes the importance of employees' work, and empowers employees, including psychologically, thus helping them gain confidence in their leaders and their achievements [19,49]. If employees believe that they can achieve high performance and trust their leaders, they are more likely to take risks [19] and perform their work more creatively and innovatively [57]. Empowering leadership also increases the emotional relationship with the organization and positively impacts performance by instilling in employees a sense of security in the organization [58]. Employees who have trust in an organization and its leaders take risks to accommodate others and improve organizations' performance in the process [59]. Coaching, which is a characteristic of empowering leadership, encourages new ideas and risk-taking behavior and provides feedback over the course of a task, thus allowing employees to view failures and mistakes as learning opportunities [60]. Empowering leadership makes employees feel confident and secure within the organization by allowing them to work autonomously and provides support for capacity development $[18,61]$. In this process, employees' mistakes and failures are considered a learning opportunity, thus encouraging them to take risks and try new things. Leaders that show interest in employees through empowering leadership help alleviate employees' fear, anxieties, and stress [61]. Empowering leadership reduces the negative emotions of employees and helps instill belief in the organization and its leaders, while preparing them to positively accept any negative consequences of change. As a result, empowering leadership can help employees find meaning in their work and feel secure within the organization, while also promoting creativity and reducing defensive behavior against risk. Thus, empowering leadership will have a positive impact on employees' risk-taking behavior.

Empowerment has a direct impact on employees' psychological state [31]. Empowerment helps clarify goals and visions and empowers employees with the necessary authority and autonomy, instilling confidence and enabling them to develop a positive psychological state [62]. Eventually, employees with a positive psychological state and confidence will actively engage in organizational change and undertake risks without fear of negative consequences. Although innovation and change, like development of a new product-development or processes, present a risk associated with failure [63], individuals who take risks tend to focus on a positive outcome rather than failure and perceive risk as an opportunity [64]. Individuals with a preference for risk are more committed to new initiatives and processes, such as organizational change [65], because they seek to capture and create new opportunities.

Thus, risk-taking behavior can be a result of empowering leadership and an antecedent for commitment to organizational change. Empowering leadership delegates authority, responsibility, and autonomy to employees [17]. With the necessary authority and autonomy, employees trust and follow leaders and organizations $[18,19,58]$. Furthermore, employees can promote risk-taking behavior by reducing fear, anxiety, and stress [17,29,61]. Risk-taking behavior allows employees to take risks and decrease their fear of change, making it an important factor in inducing commitment to organizational change. Thus, empowering leadership indirectly promotes commitment to organizational change through risk-taking behavior. Therefore, we hypothesize the following:

Hypothesis 2. Risk-taking behavior positively mediates the relationship between empowering leadership and commitment to organizational change.

\subsection{Moderating Role of Task Complexity}

A complex task refers to a task that requires mentally challenging and complex skills [66]. Task complexity can be defined as a property that increases the amount and diversity of information related to a job $[67,68]$. Moreover, there are several factors that determine task complexity, such as the time required to the perform the task, changing conditions and repeatability, uncertainty between 
performance and goals, the number of inputs, and the skills required to perform the task [30]. High task complexity, unlike simple and repetitive tasks, is characterized by the possibility of changing routine, job, and organizational structures.

Complex tasks are not routine and standardized, and can be ambiguous and unstructured [69]. There is even a possibility that performing the task may involve changes and risks. However, individuals who are comfortable at taking risks make an effort in changing their current state to pursue new ventures. When performing complex tasks, employees achieve a sense of accomplishment, motivation, and self-efficacy [70]. As such, employees who take risks and perform complex tasks are more committed to new methods and changes even when their job is not standardized and structured. Performing tasks of high complexity can affect motivation and stimulate individuals to become more motivated [71]. Therefore, in situations that require organizational change, members will take risks and put more effort into making changes in the face of complex tasks.

According to the cognitive evaluation theory [72], job and task characteristics influence motivation. If employees are satisfied with their jobs, they will be motivated to perform better [73]. As complex tasks give employees a sense of achievement, self-efficacy, and autonomy, they are willing to take risks, explore new pathways, and perform tasks without being bound by existing rules and procedures.

In addition, high task complexity motivates employees to pursue efficient strategies for successful task performance [68]. If the task complexity for employees with risk-taking behavior is high, they are motivated for the successful operation of the organization. In addition, if an organization needs to change, employees are willing to undertake more risks and operate the organization more efficiently. Therefore, employees who take risks in their work are more motivated to perform tasks more efficiently and committed to organizational change if they perform complex tasks. Thus, we hypothesize the following:

Hypothesis 3. Task complexity moderates the relationship between risk-taking behavior and commitment to organizational change such that a positive relationship is stronger when task complexity is high.

\subsection{Integrated Model: Mediated Moderation}

The above-hypothesized pattern of moderation implies mediated moderation, whereby a mediated effect varies as a function of a third variable [74]. Specifically, when task complexity is high, the effect of risk-taking behavior on commitment to organizational change is augmented, thereby strengthening the role of risk-taking behavior in mediating the relationship between empowering leadership and commitment to organizational change. By contrast, when task complexity is low, the positive effect of risk-taking behavior is weakened, thereby reducing its mediating effect. Thus, we expect task complexity to moderate the indirect effect of empowering leadership on commitment to organizational change through risk-taking behavior. Thus, we hypothesize:

Hypothesis 4. The strength of the mediated relationship between empowering leadership and commitment to organizational change via risk-taking behavior varies depending on the extent of task complexity; the indirect effect of empowering leadership via risk-taking behavior on commitment to organizational change is stronger when task complexity is high.

This study empirically analyzes the mediated moderation effects of task complexity. Figure 1 summarized the proposed relationships. 


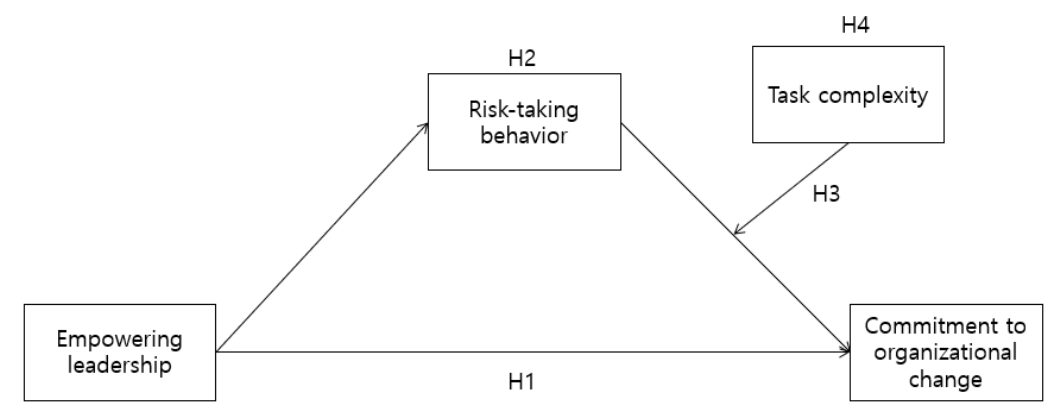

Figure 1. Hypothesized research model.

\section{Method}

\subsection{Sample and Procedure}

The data collection for this study was conducted through an online and offline questionnaire from March to May 2019. The survey procedure was conducted for employees working in Korean manufacturing and service companies. We visited the company and explained the intent of the survey to the department managers and received their permission. We collected 320 questionnaires, of which 275 valid questionnaires were used for this study. The demographic characteristics of respondents are as follows.

Among the 275 respondents of this study, $153(55.6 \%)$ were male and $122(44.4 \%)$ were female. The average age of the respondents was 30.13 years $(\mathrm{SD}=8.25)$, mean organizational tenure was 4.15 years $(S D=5.34)$, and average duration of education was 15.59 years $(S D=2.04)$.

\subsection{Measures}

The questionnaire used in this study was originally prepared in English and translated into Korean. We followed the Brislin [75] back translation procedure. A professional translator was used to translate the original version into Korean, which was then back-translated into English by a bilingual scholar who had no prior knowledge of the objectives of the study and had not seen the original survey.

Empowering leadership. Empowering leadership is defined as the act of a leader delegating authority to members and enhancing their autonomy and responsibility [21]. We used the twenty items that were developed by Arnold et al. [18]. These are twenty items of empowering leadership that reflect five characteristics: leading by example, participative decision-making, coaching, informing, and showing concern. Sample items include the following: "My boss is always working as hard as he/she can" (leading by example); "My boss gives all work group members a chance to voice their opinions" (participative decision-making); "My boss teaches work group members how to solve problems on their own" (coaching); "My boss explains his/her decisions and actions to my work group" (informing); "My boss shows concern for the well-being of the work group members" (showing concern). The Cronbach's $\alpha$ of the summative scale was 0.970 .

Risk-taking behavior. Risk-taking behavior is defined as the willingness and behavior of individuals to engage in potential risks at work in an effort to produce positive outcomes for organizations such that he/she is open to the possibility of negative personal outcomes [29]. We used the eight items developed by Dewett [29]. Sample items include the following: "I will take a risk and try something new if I have an idea that might improve my work, regardless of how I am evaluated"; "Even if failure is a possibility, I will take informed risks on the job if I think they will help me reach my goals". The Cronbach's $\alpha$ of the summative scale was 0.929 .

Commitment to organizational change. Herscovitch and Meyer [43] define commitment to organizational change as "a mind-set that binds an individual to a course of action deemed necessary for the successful implementation of a change initiative." We used the six items developed by Herscovitch and Meyer [43]. Sample items include the following: "This change is a good strategy for this 
organization"; and "I believe in the value of this change". The Cronbach's $\alpha$ of the summative scale was 0.888 .

Task complexity. Task complexity is defined as an attribute of a task that increases the amount and diversity of information related to a job [67]. Sample items include: "My job is complicated"; and "My job requires high problem-solving skills". The Cronbach's $\alpha$ of the summative scale was 0.893 .

Control variables. To clarify the relationship between the variables in this study, we controlled for the effects of demographic characteristics. Therefore, the gender, age, tenure, rank, and education level of the respondents were considered as control variables. Age and tenure were measured in years. Gender was measured as a dichotomous variable, coded as 0 for male and 1 for female. Education was measured as years of formal education.

\section{Results}

\subsection{Correlation and Reliability Analyses}

We conducted a correlation analysis to investigate the relationship between the measured variables and its direction. The means, standard deviations, reliabilities, and correlations among the key variables are shown in Table 1. As shown, commitment to organizational change was related to empowering leadership $(r=0.351, p<0.001)$, risk-taking behavior $(r=0.442, p<0.001)$, and task complexity $(\mathrm{r}=0.490, p<0.001)$.

Table 1. Means, standard deviations, correlations, and reliabilities.

\begin{tabular}{|c|c|c|c|c|c|c|c|c|c|c|c|}
\hline Variable & Mean & SD & 1 & 2 & 3 & 4 & 5 & 6 & 7 & 8 & 9 \\
\hline 1. Gender $(0=\mathrm{M} ; 1=\mathrm{F})^{\mathrm{a}}$ & 0.44 & 0.49 & & & & & & & & & \\
\hline 2. Age & 30.13 & 8.25 & -0.067 & & & & & & & & \\
\hline 3. Tenure ${ }^{b}$ & 4.15 & 5.34 & -0.050 & $0.779^{* * *}$ & & & & & & & \\
\hline 4. Position & 1.69 & 1.04 & -0.111 & $0.637^{* * *}$ & $0.635^{* * *}$ & & & & & & \\
\hline 5. Education ${ }^{c}$ & 15.59 & 2.0 & -0.045 & $0.382^{* * *}$ & $0.317^{* * *}$ & $0.308^{* * *}$ & & & & & \\
\hline $\begin{array}{l}\text { 6. Empowering } \\
\text { Leadership }\end{array}$ & 3.49 & 0.91 & -0.063 & 0.049 & 0.110 & 0.072 & 0.057 & $(0.970)$ & & & \\
\hline 8. Task Complexity & 3.40 & 1.07 & -0.019 & 0.072 & 0.069 & $0.181^{* *}$ & 0.077 & $0.230^{* * *}$ & $0.396^{* * *}$ & $(0.893)$ & \\
\hline $\begin{array}{l}\text { 9. Commitment to } \\
\text { Organizational Change }\end{array}$ & 3.75 & 0.72 & -0.071 & -0.018 & 0.026 & 0.008 & 0.084 & $0.351^{* * *}$ & $0.442^{* * *}$ & $0.490^{* * *}$ & $(0.888)$ \\
\hline
\end{tabular}

Note: $N=275$. ${ }^{*} p<0.05 ;{ }^{* *} p<0.01 ;{ }^{* * *} p<0.001$. Reliability alpha $(\alpha)$ coefficients are reported in diagonal;

${ }^{\mathrm{a}} \mathrm{M}=$ male; $\mathrm{F}=$ female,${ }^{\mathrm{b}}$ Tenure $=$ number of years,${ }^{\mathrm{c}}$ Education $=$ years of formal education.

In addition, we analyzed the reliability to verify that the measured data were suitable for empirical analysis prior to hypothesis testing. The Cronbach's $\alpha$ exceeded 0.70 , indicating that the reliability of the measurement tool is high [76].

\subsection{Common Method Bias and Confirmatory Factor Analysis}

To assess the tests of common method variance, we followed the recommendation by Podsakoff, MacKenzie, Lee, and Podsakoff [77] and conducted Harman's single-factor test by loading all the items of the study constructs into an exploratory factor analysis. The results indicate that no single factor explains more than $34 \%$ of the covariance among the variables.

We also conducted a confirmatory factor analysis (CFA) on the measures of the key variables to verify their factor structure and construct validity. We modeled four factors: empowering leadership, risk-taking behavior, task complexity, and commitment to organizational change. The results are shown in Table 2. This theoretical four-factor model provided a reasonable fit to the data $(\chi 2=718.778$, degree of freedom $(\mathrm{df})=547$, Comparative Fit Index $(\mathrm{CFI})=0.980$, Tucker-Lewis Index (TLI) $=0.976$, Root Mean Square Residual(RMR) $=0.054$, Root Mean Square Error of Approximation(RMSEA $=0.034$ ). Additionally, a series of Chi-square difference tests revealed that the four-factor model fits the data significantly better than several alternative measurement models (Table 2). The results verify the theoretical four-factor model, thus supporting discriminant validity among the measures. 
Table 2. Model fit statistics for measurement models.

\begin{tabular}{|c|c|c|c|c|c|c|}
\hline Measurement Model & $\chi^{2}(d f)$ & CFI & TLI & RMR & RMSEA & $\Delta \times 2(d f)$ \\
\hline Theoretical 4-factor model & $718.778(547)$ & 0.980 & 0.976 & 0.054 & 0.034 & \\
\hline 3-factor model ${ }^{1}$ & $1186.838(550)$ & 0.928 & 0.912 & 0.081 & 0.065 & $468.06(3)^{* * *}$ \\
\hline 2 -factor model ${ }^{2}$ & $1627.165(553)$ & 0.878 & 0.853 & 0.106 & 0.084 & $908.387(6)^{* * *}$ \\
\hline 1 -factor model ${ }^{3}$ & $2277.279(555)$ & 0.804 & 0.765 & 0.131 & 0.106 & $1558.501(8)^{* * *}$ \\
\hline
\end{tabular}

Note: $n=275 .{ }^{* * *} p<0.001$ (two-tailed test). ${ }^{1}$ Three-factor model with risk-taking behavior and task complexity on the same factor. ${ }^{2}$ Two-factor model with empowering leadership and risk-taking behavior, task complexity and commitment to organizational change on the same factor. ${ }^{3}$ One-factor model with empowering leadership, task complexity, risk-taking behavior and commitment to organizational change on the same factor. $\chi^{2}=$ chi-square, $\mathrm{df}=$ degrees of freedom, CFI = Comparative Fit Index, TLI = Tucker-Lewis Index, RMR= Root Mean Square Residual, RMSEA = Root Mean Square Error of Approximation.

The index for the overall confirmatory factor analysis is presented in Table 3 . The results of the confirmatory factor analysis were $\chi 2(\mathrm{df})=718.778(547)$, Incremental Fit Index $(\mathrm{IFI})=0.981$, TLI $=0.976$, $\mathrm{CFI}=0.980$, Goodness-of-Fit Index $(\mathrm{GFI})=0.883, \mathrm{RMR}=0.054$, RMSEA $=0.034$, Normed Fit Index $(\mathrm{NFI})=0.924$, and Adjusted Goodness-of-Fit Index (AGFI) $=0.850$. As shown in Table 3, although GFI is not in the best model indicator, $\chi 2$ (df), IFI, TLI, CFI, RMSEA, and NFI are included in the best model indicator, and the values of AGFI and RMR are at acceptable levels [78]. Therefore, the results of confirmatory factor analysis can be considered acceptable. In addition, the average variance extracted (AVE), the variance size that explains the concept of the measurement variables, is greater than 0.5 , which is the reference value. The construct reliability value exceeded 0.7 , thus supporting convergent validity and reliability of the constructs $[79,80]$.

Table 3. Results of confirmatory factor analysis[m1] .

\begin{tabular}{|c|c|c|c|c|c|c|c|}
\hline Construct & Item & $\begin{array}{l}\text { Standardized } \\
\text { Factor Loading }\end{array}$ & $\begin{array}{l}\text { Standard } \\
\text { Error }\end{array}$ & $\begin{array}{l}\text { Critical } \\
\text { Ratio }\end{array}$ & $\begin{array}{l}\text { Average Variance } \\
\text { Extracted (AVE) }\end{array}$ & $\begin{array}{l}\text { Construct } \\
\text { Reliability }\end{array}$ & $\begin{array}{l}\text { Goodness of Fit } \\
\text { Index }\end{array}$ \\
\hline \multirow{20}{*}{$\begin{array}{l}\text { Empowering } \\
\text { Leadership }\end{array}$} & EL1 & 0.834 & & & \multirow{20}{*}{0.548} & \multirow{20}{*}{0.947} & \multirow{20}{*}{$\begin{array}{c}\chi^{2}=718.778 \\
\mathrm{df}=547 \\
p=0.000 \\
\mathrm{IFI}=0.981 \\
\mathrm{TLI}=0.976 \\
\mathrm{CFI}=0.980 \\
\mathrm{GFI}=0.883 \\
\text { RMR }=0.054 \\
\text { RMSEA }=0.034 \\
\text { NFI }=0.924 \\
\text { AGFI }=0.850\end{array}$} \\
\hline & EL2 & 0.735 & 0.048 & 16.853 & & & \\
\hline & EL3 & 0.800 & 0.051 & 20.091 & & & \\
\hline & EL4 & 0.830 & 0.051 & 20.997 & & & \\
\hline & EL5 & 0.818 & 0.060 & 16.541 & & & \\
\hline & EL6 & 0.735 & 0.061 & 14.344 & & & \\
\hline & EL7 & 0.731 & 0.057 & 14.254 & & & \\
\hline & EL8 & 0.733 & 0.061 & 14.304 & & & \\
\hline & EL9 & 0.777 & 0.060 & 15.563 & & & \\
\hline & EL10 & 0.832 & 0.054 & 18.543 & & & \\
\hline & EL11 & 0.875 & 0.055 & 18.717 & & & \\
\hline & EL12 & 0.814 & 0.059 & 16.515 & & & \\
\hline & EL13 & 0.736 & 0.055 & 14.55 & & & \\
\hline & EL14 & 0.728 & 0.059 & 14.11 & & & \\
\hline & EL15 & 0.757 & 0.059 & 15.25 & & & \\
\hline & EL16 & 0.867 & 0.057 & 18.533 & & & \\
\hline & EL17 & 0.726 & 0.062 & 14.079 & & & \\
\hline & EL18 & 0.75 & 0.066 & 14.769 & & & \\
\hline & EL19 & 0.814 & 0.061 & 16.934 & & & \\
\hline & EL20 & 0.712 & 0.064 & 13.752 & & & \\
\hline \multirow{8}{*}{$\begin{array}{c}\text { Risk-taking } \\
\text { Behavior }\end{array}$} & RT1 & 0.786 & & & \multirow{8}{*}{0.590} & \multirow{8}{*}{0.920} & \\
\hline & RT2 & 0.748 & 0.061 & 15.07 & & & \\
\hline & RT3 & 0.833 & 0.069 & 15.14 & & & \\
\hline & RT4 & 0.842 & 0.069 & 15.114 & & & \\
\hline & RT5 & 0.791 & 0.069 & 13.973 & & & \\
\hline & RT6 & 0.795 & 0.067 & 14.127 & & & \\
\hline & RT7 & 0.76 & 0.071 & 13.514 & & & \\
\hline & RT8 & 0.695 & 0.08 & 12.261 & & & \\
\hline
\end{tabular}


Table 3. Cont.

\begin{tabular}{|c|c|c|c|c|c|c|c|}
\hline Construct & Item & $\begin{array}{l}\text { Standardized } \\
\text { Factor Loading }\end{array}$ & $\begin{array}{l}\text { Standard } \\
\text { Error }\end{array}$ & $\begin{array}{l}\text { Critical } \\
\text { Ratio }\end{array}$ & $\begin{array}{l}\text { Average Variance } \\
\text { Extracted (AVE) }\end{array}$ & $\begin{array}{l}\text { Construct } \\
\text { Reliability }\end{array}$ & $\begin{array}{l}\text { Goodness of Fit } \\
\text { Index }\end{array}$ \\
\hline \multirow{3}{*}{ Task Complexity } & TC1 & 0.901 & & & \multirow{3}{*}{0.660} & \multirow{3}{*}{0.856} & \\
\hline & TC2 & 0.858 & 0.05 & 18.482 & & & \\
\hline & TC3 & 0.804 & 0.055 & 16.976 & & & \\
\hline \multirow{6}{*}{$\begin{array}{l}\text { Commitment to } \\
\text { Organizational Change }\end{array}$} & COC1 & 0.756 & & & \multirow{6}{*}{0.588} & \multirow{6}{*}{0.894} & \\
\hline & COC2 & 0.861 & 0.077 & 14.506 & & & \\
\hline & COC3 & 0.831 & 0.079 & 14.014 & & & \\
\hline & COC4 & 0.643 & 0.093 & 10.127 & & & \\
\hline & COC5 & 0.647 & 0.09 & 10.555 & & & \\
\hline & COC6 & 0.637 & 0.088 & 10.27 & & & \\
\hline
\end{tabular}

\subsection{Hypotheses Testing}

We tested Hypotheses 1-3 by hierarchical regression analysis and the results are presented in Table 4. We calculated the interaction terms needed to verify the moderating effects in Hypothesis 3. Before calculating the interaction term, we attempted to solve the problem of multicollinearity by performing a mean-centering method [81]. The result of analyzing the value of the variance inflated index, the maximum VIF of the key variables is 1.763 . Hence, there is no multicollinearity problem.

Table 4. Hierarchical multiple regression for risk-taking behavior and commitment to organizational change.

\begin{tabular}{|c|c|c|c|c|c|c|}
\hline & \multicolumn{3}{|c|}{ Risk-Taking Behavior } & \multicolumn{3}{|c|}{ Commitment to Organizational Change } \\
\hline & Model 1 & Model 2 & Model 3 & Model 4 & Model 5 & Model 6 \\
\hline Gender & -0.014 & 0.018 & -0.071 & -0.051 & -0.058 & -0.054 \\
\hline Age & 0.016 & 0.080 & -0.136 & -0.096 & -0.126 & -0.121 \\
\hline Tenure & 0.075 & -0.022 & 0.102 & 0.042 & 0.050 & 0.102 \\
\hline Position & 0.052 & 0.043 & -0.010 & -0.015 & -0.031 & -0.112 \\
\hline Education & -0.049 & -0.071 & 0.103 & 0.090 & $0.116^{*}$ & 0.098 \\
\hline Empowering Leadership & & $0.555^{* * *}$ & & $0.344^{* * *}$ & $0.136^{*}$ & $0.133^{*}$ \\
\hline Risk-Taking Behavior & & & & & $0.375^{* * *}$ & $0.175^{* *}$ \\
\hline Task Complexity & & & & & & $0.387^{* * *}$ \\
\hline Risk-Taking Behavior $\times$ Task Complexity & & & & & & $0.160^{* *}$ \\
\hline $\mathrm{R}^{2}$ & 0.015 & 0.316 & 0.019 & 0.135 & 0.231 & 0.373 \\
\hline$\Delta \mathrm{R}^{2}$ & & $0.301^{* * *}$ & & $0.116^{* * *}$ & $0.096^{* * *}$ & $0.143^{* * *}$ \\
\hline
\end{tabular}

Note: $n=275 .{ }^{*} p<0.05 ;{ }^{* *} p<0.01 ;{ }^{* * *} p<0.001$ (two-tailed test). Standardized regression coefficients reported.

Supporting Hypothesis 1, empowering leadership was found to be positively related to commitment to organizational change $(\beta=0.344, p<0.001)$ after controlling for gender, age, tenure, rank, and education level in Model 4 . To test the mediating role of risk-taking behavior in the relationship between empowering leadership and commitment to organizational change in Hypothesis 2, we followed the procedure established by Baron and Kenny [82]. First, by testing Hypothesis 1, we verified the positive effect of empowering leadership on commitment to organizational change. Next, in Model 2, empowering leadership was positively related to risk-taking behavior $(\beta=0.555, p<0.001)$. Finally, in Model 5, risk-taking behavior was positively related to commitment to organizational change ( $\beta=0.375, p<0.001$ ), explaining significant additional variance in commitment to organizational change $\left(\Delta R^{2}=0.096, p<0.001\right)$. The effect of empowering leadership on commitment to organizational change became weaker, but it was still significant $(\beta=0.136, p<0.05)$. However, errors can occur because this is an indirect method for statistical estimation of mediating effect. To further substantiate this result, we applied Preacher and Hayes' [83] test for an indirect effect, which utilizes the bootstrap method for more reliable estimates. The results of the bootstrap method confirmed a significant indirect effect (indirect effect $=0.1620, \mathrm{SE}=0.0366,95 \%$ CI $[0.0967,0.2398]$ ). Thus, Hypothesis 2 was supported .

In Hypothesis 3, we proposed that task complexity moderates the relationship between risk-taking behavior and commitment to organizational change. As regards the moderating role of task complexity, the interaction term of risk-taking behavior and task complexity significantly predicted commitment 
to organizational change $\left(\beta=0.160, p<0.01 ; \Delta R^{2}=0.143, p<0.001\right)$ in Model 6. In Figure 2, a graph distinguishes high and low task complexity groups with respect to the average value of task complexity. As shown in Figure 2, there was a difference in the relationship between risk-taking behavior and commitment to organizational change depending on the degree of task complexity. Thus, Hypothesis 3 was supported.

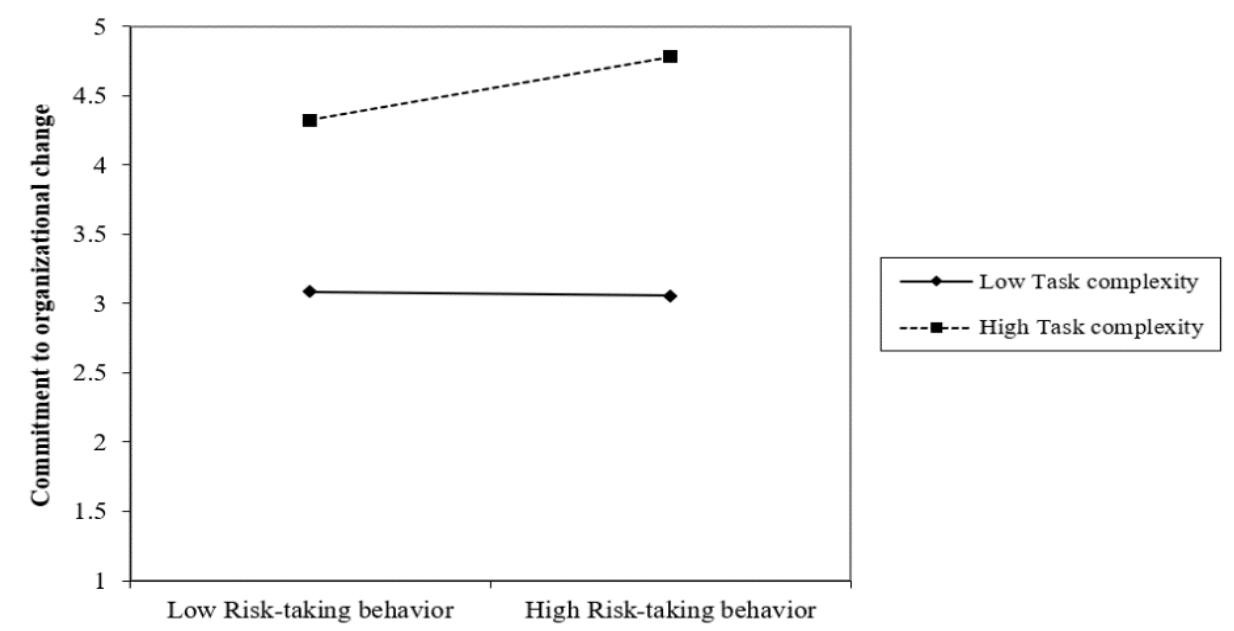

Figure 2. The moderating effect of task complexity on the relationship between risk-taking behavior and commitment to organizational change.

To test for integrative mediated moderation in Hypothesis 4, we examined whether the indirect effect of empowering leadership on commitment to organizational change via risk-taking behavior was moderated by task complexity (i.e., conditional indirect effect). To test the conditional indirect effect, we utilized Hayes' [84] PROCESS program. The technical system of equations for our analytical model is presented visually in the form of a path diagram in Figure 3. This diagram presents a process in which the commitment to organizational change that results from empowering leadership $(X)$ occurs through the risk-taking behavior $(M)$, which in turn leads to the commitment to organizational change $(Y)$. However, the link between risk-taking behavior and commitment to organizational change-the second stage of the mechanism -is modeled as moderated by task complexity $(W)$. This process is modeled with two equations, one for risk-taking behavior and one for commitment to organizational change:

$$
\begin{gathered}
M=i_{M}+a_{1} X+a_{2} U+e_{M} \\
Y=i_{Y}+c^{\prime} X+b_{1} M+b_{2} W+b_{3} M W+b_{4} U+e_{Y},
\end{gathered}
$$

where $U$ is the control variables.

The indirect effect of empowering leadership on commitment to organizational change via risk-taking behavior was estimated for high (+1 SD) and low levels ( $-1 \mathrm{SD})$ of task complexity using the bootstrap method. The analysis results are presented in Table 5. The results indicate that the indirect effect was significant for high task complexity (conditional indirect effect $=0.1499, \mathrm{SE}=0.0397$, $95 \%$ CI $[0.0761,0.2332]$ ), but not significant for low task complexity (conditional indirect effect $=0.0139$, $\mathrm{SE}=0.0532,95 \% \mathrm{CI}[-0.0785,0.1285])$, thus supporting Hypothesis 4 . 


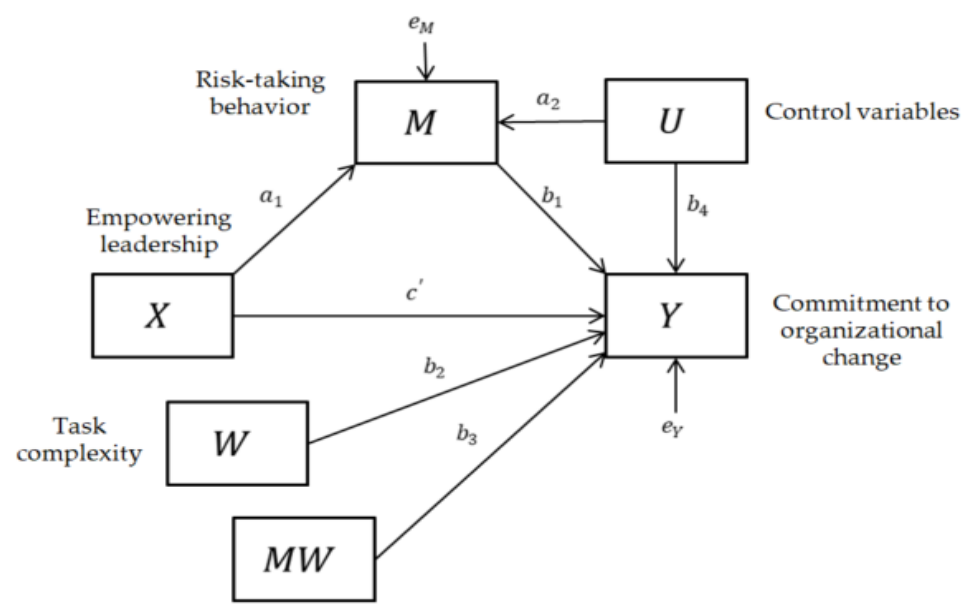

Figure 3. The form of the statistical model for the mediated moderating effect.

Table 5. Mediated moderation results for conditional indirect effect.

\begin{tabular}{ccccc}
\hline Task Complexity & $\begin{array}{c}\text { Boot Indirect } \\
\text { Effect }(\boldsymbol{\beta})\end{array}$ & Boot SE & \multicolumn{2}{c}{ 95\% of Confidence Intervals } \\
Boot LLCI & Boot ULCI \\
\hline M - 1SD & 0.0139 & 0.0532 & -0.0785 & 0.1285 \\
Mean & 0.0819 & 0.0348 & 0.0169 & 0.1559 \\
$M+1 S D$ & 0.1499 & 0.0397 & 0.0761 & 0.2332 \\
\hline
\end{tabular}

\section{Discussion}

This study examined the relationship between empowering leadership and the commitment to organizational change of manufacturing and service workers in Korea, and examined the mediating role of risk-taking behavior in the relationship between empowering leadership and commitment to organizational change. Furthermore, the mediated moderating effects of task complexity were investigated. The results are summarized as follows.

First, empowering leadership had a positive effect on the commitment to organizational change. It was concluded that empowering leader behavior (i.e., leading by example, participative decision-making, coaching, informing, and showing concern) had a positive effect on commitment to organizational change. These empirical results support previous studies on empowering leadership and commitment to organizational change [20,85]. Furthermore, our study enhanced the understanding of the significance of empowering leadership as a type of sustainable leadership in evoking a positive attitude and behavior toward organizational change from employees, thus leading to the sustainable development of the organization. Second, risk-taking behavior positively mediated the relationship between empowering leadership and commitment to organizational change. Therefore, it should be considered as an important psychological mechanism leading to commitment to organizational change [86]. These empirical findings are in line with previous research that finds evidence for the influence risk-taking behavior has on factors related to organizational change, such as creativity and innovation $[87,88]$.

Third, task complexity was positively moderating the relationship between risk-taking behavior and commitment to organizational change. We also confirmed the conditional indirect effect of task complexity using the mediated moderation model proposed in this study. More specifically, we examined how the mediating effect depends on the degree of task complexity, which is a moderation variable. High task complexity augmented the mediating effect of risk-taking behavior on commitment to organizational change, which, in turn, is further affected by empowering leadership.

This study has made theoretical contributions to the existing literature in the following ways. First, it contributes to the literature on empowering leadership and organizational change by addressing the effect of empowering leadership on employees' commitment to organizational change. Most 
previous studies have treated empowering leadership simply as a positive factor affecting individual attitudes, such as self-efficacy, optimism, and job performance [18,89]. However, our study extends and complements these previous findings by empirically demonstrating the key role of empowering leadership in inducing employees' commitment to organizational change.

Second, this study extended the literature on empowering leadership by adding a key mediator to explicate how empowering leadership induces commitment to organizational change. Thus, our findings show that risk-taking behavior is an important bridging mechanism, through which empowering leadership motivates employees to take proactive action despite fears and concerns about change. This study applies risk-taking behavior, which is mainly dealt with in psychology and sociology $[90,91]$, to organizational change in relation to leadership. In particular, by identifying risk-taking behavior as a crucial psychological and behavioral pathway influencing employees' attitude towards organizational change, this study enriched our understanding of how empowering leadership promoted employees' commitment to organizational change.

Third, this study identified task complexity as an important moderator of the effect of empowering leadership. By identifying such a boundary condition, this study provided a more precise understanding of the role that empowering leadership plays in the process of organizational change. Moreover, identifying the mediated moderation effect of empowering leadership on commitment to organizational change via risk-taking behavior has further extended prior research on mediators and moderators of the relationship between empowering leadership and organizational change. In other words, our findings provide a holistic view concerning the direct and indirect mechanisms and conditions of how empowering leadership promotes employees' commitment to organizational change in a complex business environment.

\subsection{Practical Implications}

We also suggest several practical implications based on our results. First, our results indicate that managers should be aware of the effectiveness of empowering leadership, which positively impacts commitment to organizational change, leading to the sustainable growth of the organization. When organizational change is needed, most members are indifferent to change and resist it [92]. Therefore, if managers provide empowerment, autonomy, and responsibility to employees through empowering leadership, they can make the employees more proactive in the implementing process of change. In particular, participative decision-making will have a positive impact on job attitudes and behaviors by providing employees with psychological empowerment $[19,93]$. Therefore, organizations will need to design an empowering leadership development training and education program for managers.

Second, managers should recognize the importance of employees' risk-taking behavior. Employees' risk-taking behavior has a positive impact on emotional commitment and proactiveness [94], which will have a positive impact on organizational change and sustainable performance. Thus, managers should design an organizational support system and facilitate a climate for fostering employees' risk-taking behavior. Specifically, managers need to design a system that reflects employee opinions and stimulates confidence in their work. For example, adopting a participative decision-making system and redesigning the reward system will allow employees to take risks and pursue change with a positive attitude and confidence.

Third, our results also indicate that task characteristic is an important condition for enhancing employees' commitment to organizational change. Task complexity increases skill variety, task significance and autonomy, which can affect motivation and the psychological state of employees with respect to organizational change [95]. As such, task complexity can help employees recognize the importance of organizational change. We suggest a high task complexity situation as an important condition for enhancing the effects of empowering leadership and risk-taking behavior on commitment to organizational change. 


\subsection{Limitations and Future Research}

Despite the important implications of this study, it has its own limitations. First, as a cross-sectional study, it restricts causal inferences from the chosen variables. Moreover, as the data were collected through a self-report questionnaire, there is a possibility of a common method bias problem [96]. To reduce this problem, we tried to ensure anonymity in the data collection process and undertook a statistical treatment. Despite these efforts, we recommend separating the source of measurement of the variables or measuring at different times to solve the common method bias problem. For example, leadership can be measured by employees and employees' performance can be measured by leaders. Second, we conducted our research at the individual level because we were interested in how empowering leadership influences commitment to organizational change. However, leadership was originally theorized as a group-level construct grounded in the psychology and social relations of members [97]. Therefore, future research should conduct team-level or multi-level analyses. Finally, future studies need to identify various psychological factors in the relationship between empowering leadership and commitment to organizational change. Although task complexity was introduced as a conditional variable in this study, future studies can explore various other moderators such as organizational climate and culture.

\section{Conclusions}

This study sought to contribute to the growing literature on organizational change by examining the role of empowering leadership in facilitating employees' commitment. We predicted and empirically proved that risk-taking behavior is a mediating factor in the relationship between empowering leadership and commitment to organizational change (indirect effect $=0.1620, \mathrm{SE}=0.0366$, $95 \%$ CI $[0.0967,0.2398])$. In addition, we confirmed task complexity as a boundary condition in the relationship between risk-taking behavior and commitment to organizational change $(\beta=0.160$, $\left.p<0.01 ; \Delta \mathrm{R}^{2}=0.143, p<0.001\right)$. We also found that the mediating role of risk-taking behavior is significant under high task complexity (conditional indirect effect $=0.1499, \mathrm{SE}=0.0397,95 \% \mathrm{CI}[0.0761$, $0.2332]$ ), but insignificant when task complexity is low (conditional indirect effect $=0.0139$, $\mathrm{SE}=0.0532$, $95 \%$ CI $[-0.0785,0.1285])$. Despite the potential limitations of this study, our findings contribute to the growing literature on empowering leadership and organizational change by providing a deeper understanding of the mechanisms and dynamic interactions that influence employees' commitment to organizational change.

Author Contributions: K.B.J. was the principal researcher and prepared the first draft of the article under the supervision of S.B.C. S.-W.K. added valuable theoretical and methodological insights based on his knowledge and expertise on the topic of this study. S.B.C. supervised the study and refined the draft into a publishable article. All authors have read and agreed to the published version of the manuscript.

Funding: This research received no external funding.

Conflicts of Interest: The authors declare no conflicts of interest.

\section{References}

1. Ketprapakorn, N. Toward an Asian corporate sustainability model: An integrative review. J. Clean. Prod. 2019, 239, 117995. [CrossRef]

2. Abrell-Vogel, C.; Rowold, J. Leaders' commitment to change and their effectiveness in change-a multilevel investigation. J. Organ. Chang. Manag. 2014, 27, 900-921. [CrossRef]

3. Audia, P.G.; Brion, S. Reluctant to change: Self-enhancing responses to diverging performance measures. Organ. Behav. Hum. Decis. Process. 2007, 102, 255-269. [CrossRef]

4. Ming-Chu, Y.; Meng-Hsiu, L. Unlocking the black box: Exploring the link between perceive organizational support and resistance to change. Asia Pac. Manag. Rev. 2015, 20, 177-183. [CrossRef] 
5. Herold, D.M.; Fedor, D.B.; Caldwell, S.D. Beyond change management: A multilevel investigation of contextual and personal influences on employees' commitment to change. J. Appl. Psychol. 2007, 92, 942-951. [CrossRef] [PubMed]

6. Collins, J.C.; Porras, J.I. Built to Last: Successful Habits of Visionary Companies; Harper Business: New York, NY, USA, 1994.

7. Lee, K.; Sharif, M.; Scandura, T.; Kim, J. Procedural justice as a moderator of the relationship between organizational change intensity and commitment to organizational change. J. Organ. Chang. Manag. 2017, 30, 501-524. [CrossRef]

8. Jaros, S. Commitment to organizational change: A critical review. J. Chang. Manag. 2010, 10, 79-108. [CrossRef]

9. Kotter, J.P. Leading Change; Harvard Business School Press: Boston, MA, USA, 1996.

10. Bray, D.W. Personnel-Centered Organizational Diagnosis; Guilford Press: New York, NY, USA, 1994; pp. $152-171$.

11. Conner, D.R. Managing at the Speed of Change: How Resilient Managers Succeed and Prosper Where Others Fail; Random House: New York, NY, USA, 1993.

12. Inceoglu, I.; Thomas, G.; Chu, C.; Plans, D.; Gerbasi, A. Leadership behavior and employee well-being: An integrated review and a future research agenda. Leadersh. Q. 2018, 29, 179-202. [CrossRef]

13. Lee, A.; Martin, R.; Thomas, G.; Guillaume, Y.; Maio, G.R. Conceptualizing leadership perceptions as attitudes: Using attitude theory to further understand the leadership process. Leadersh. Q. 2015, 26, 910-934. [CrossRef]

14. Hallinger, P.; Suriyankietkaew, S. Science mapping of the knowledge base on sustainable leadership, 1990-2018. Sustainability 2018, 10, 4846. [CrossRef]

15. Gigol, T. Influence of authentic leadership on unethical pro-organizational behaviour: The intermediate role of work engagement. Sustainability 2020, 12, 1182. [CrossRef]

16. Samul, J. Spiritual leadership: Meaning in the sustainable workplace. Sustainability 2020, 12, 267. [CrossRef]

17. Srivastava, A.; Bartol, K.M.; Locke, E.A. Empowering leadership in management teams: Effects on knowledge sharing, efficacy, and performance. Acad. Manag. J. 2006, 49, 1239-1251. [CrossRef]

18. Arnold, J.A.; Arad, S.; Rhoades, J.A.; Drasgow, F. The empowering leadership questionnaire: The construction and validation of a new scale for measuring leader behaviors. J. Organ. Behav. 2000, 21, 249-269. [CrossRef]

19. Zhang, X.; Bartol, K.M. Linking empowering leadership and employee creativity: The influence of psychological empowerment, intrinsic motivation, and creative process engagement. Acad. Manag. J. 2010, 53, 107-128. [CrossRef]

20. Ahearne, M.; Mathieu, J.; Rapp, A. To empower or not to empower your sales force? An empirical examination of the influence of leadership empowerment behavior on customer satisfaction and performance. J. Appl. Psychol. 2005, 90, 945-955. [CrossRef]

21. Lorinkova, N.M.; Pearsall, M.J.; Sims, H.P. Examining the differential longitudinal performance of directive versus empowering leadership in teams. Acad. Manag. J. 2013, 56, 573-596. [CrossRef]

22. Chen, G.; Sharma, P.N.; Edinger, S.K.; Shapiro, D.L.; Farh, J.L. Motivating and demotivating forces in teams: Cross-level influences of empowering leadership and relationship conflict. J. Appl. Psychol. 2011, 96, 541-557. [CrossRef]

23. Clutterbuck, D.; Kernaghan, S. The Power of Empowerment: Release the Hidden Talents of Your Employees; Kogan Page: London, UK, 1994.

24. Gandz, J.; Bird, F.G. The ethics of empowerment. J. Bus. Ethics. 1996, 15, 383-392. [CrossRef]

25. Jada, U.R.; Mukhopadhyay, S.; Titiyal, R. Empowering leadership and innovative work behavior: A moderated mediation examination. J. Knowl. Manag. 2019, 23, 915-930. [CrossRef]

26. Raub, S.; Robert, C. Differential effects of empowering leadership on in-role and extra-role employee behaviors: Exploring the role of psychological empowerment and power values. Hum. Relat. 2010, 63, 1743-1770. [CrossRef]

27. Zhang, S.; Ke, X.; Frank Wang, X.H.; Liu, J. Empowering leadership and employee creativity: A dual-mechanism perspective. J. Occup. Organ. Psychol. 2018, 91, 896-917. [CrossRef]

28. Martin, S.L.; Liao, H.; Campbell, E.M. Directive versus empowering leadership: A field experiment comparing impacts on task proficiency and proactivity. Acad. Manag. J. 2013, 56, 1372-1395. [CrossRef]

29. Dewett, T. Exploring the role of risk in employee creativity. J. Creat. Behav. 2006, 40, 27-45. [CrossRef] 
30. Dodd, N.G.; Ganster, D.C. The interactive effects of variety, autonomy, and feedback on attitudes and performance. J. Organ. Behav. 1996, 17, 329-347. [CrossRef]

31. Sun, L.Y.; Zhang, Z.; Qi, J.; Chen, Z.X. Empowerment and creativity: A cross-level investigation. Leadersh. Q. 2012, 23, 55-65. [CrossRef]

32. Thomas, K.W.; Velthouse, B.A. Cognitive elements of empowerment: An "interpretive" model of intrinsic task motivation. Acad. Manag. Rev. 1990, 15, 666-681.

33. Spreitzer, G.M. Psychological empowerment in the workplace: Dimensions, measurement and validation. Acad. Manag. J. 1995, 38, 1442-1465.

34. Xue, Y.; Bradley, J.; Liang, H. Team climate, empowering leadership, and knowledge sharing. J. Knowl. Manag. 2011, 15, 299-312. [CrossRef]

35. Zhang, X.; Zhou, J. Empowering leadership, uncertainty avoidance, trust, and employee creativity: Interaction effects and a mediating mechanism. Organ. Behav. Hum. Decis. Process. 2014, 124, 150-164. [CrossRef]

36. Bortoluzzi, G.; Caporale, L.; Palese, A. Does participative leadership reduce the onset of mobbing risk among nurse working teams? J. Nurs. Manag. 2014, 22, 643-652. [CrossRef] [PubMed]

37. Hersey, P.; Blanchard, K.H. Life cycle theory of leadership. Train. Dev. J. 1969, 23, 26-34.

38. Engemann, K.N.; Scott, C.W. Voice in safety-oriented organizations: Examining the intersection of hierarchical and mindful social contexts. Hum. Resour. Manag. Rev. 2020, 30, 100650. [CrossRef]

39. Hussain, S.T.; Lei, S.; Akram, T.; Haider, M.J.; Hussain, S.H.; Ali, M. Kurt Lewin's change model: A critical review of the role of leadership and employee involvement in organizational change. J. Innov. Knowl. 2018, 3, 123-127. [CrossRef]

40. Piderit, S.K. Rethinking resistance and recognizing ambivalence: A multidimensional view of attitudes toward an organizational change. Acad. Manag. Rev. 2000, 25, 783-794. [CrossRef]

41. Choi, J.N.; Sung, S.Y.; Lee, K.; Cho, D.S. Balancing cognition and emotion: Innovation implementation as a function of cognitive appraisal and emotional reactions toward innovation. J. Organ. Behav. 2011, 32, 107-124. [CrossRef]

42. Rafferty, A.E.; Jimmieson, N.L. Subjective perceptions of organizational change and employee resistance to change: Direct and mediated relationships with employee well-being. Br. J. Manag. 2017, 28, 248-264. [CrossRef]

43. Herscovitch, L.; Meyer, J.P. Commitment to organizational change: Extension of a three-component model. J. Appl. Psychol. 2002, 87, 474-487. [CrossRef]

44. Herold, D.M.; Fedor, D.B.; Caldwell, S.; Liu, Y. The effects of transformational and change leadership on employees' commitment to a change: A multilevel study. J. Appl. Psychol. 2008, 93, 346-357. [CrossRef]

45. Kim, M.; Beehr, T.A.; Prewett, M.S. Employee responses to empowering leadership: A meta-analysis. J. Leadersh. Organ. Stud. 2018, 25, 257-276. [CrossRef]

46. Allen, S.; Winston, B.E.; Tatone, G.R.; Crowson, H.M. Exploring a model of servant leadership, empowerment, and commitment in nonprofit organizations. Nonprofit Manag. Leadersh. 2018, 29, 123-140. [CrossRef]

47. Morin, A.J.; Meyer, J.P.; Bélanger, É.; Boudrias, J.S.; Gagné, M.; Parker, P.D. Longitudinal associations between employees' beliefs about the quality of the change management process, affective commitment to change and psychological empowerment. Hum. Relat. 2016, 69, 839-867. [CrossRef]

48. Parish, J.T.; Cadwallader, S.; Busch, P.; Busch. Want to, need to, ought to: Employee commitment to organizational change. J. Organ. Chang. Manag. 2007, 21, 32-52. [CrossRef]

49. Lee, A.; Willis, S.; Tian, A.W. Empowering leadership: A meta-analytic examination of incremental contribution, mediation, and moderation. J. Organ. Behav. 2018, 39, 306-325. [CrossRef]

50. Armenakis, A.A.; Harris, S.G.; Mossholder, K.W. Creating readiness for organizational change. Hum. Relat. 1993, 46, 169-183. [CrossRef]

51. Shea, C.M.; Jacobs, S.R.; Esserman, D.A.; Bruce, K.; Weiner, B.J. Organizational readiness for implementing change: A psychometric assessment of a new measure. Implement. Sci. 2014, 9, 7. [CrossRef]

52. Fugate, M. The impact of leadership, management, and HRM on employee reactions to organizational change. Res. Pers. Hum. Resour. Manag. 2012, 31, 177-208.

53. Wanberg, C.R.; Banas, J.T. Predictors and outcomes of openness to changes in a reorganizing workplace. J. Appl. Psychol. 2000, 85, 132-142. [CrossRef]

54. Laschinger, H.K.S.; Fida, R. New nurses burnout and workplace wellbeing: The influence of authentic leadership and psychological capital. Burn. Res. 2014, 1, 19-28. [CrossRef] 
55. Yates, J. Risk-Taking Behavior; John Wiley \& Sons: Oxford, UK, 1992.

56. Sitkin, S.B.; Pablo, A.L. Reconceptualizing the determinants of risk behavior. Acad. Manag. Rev. 1992, 17, 9-38. [CrossRef]

57. McCauley, D.P.; Kuhnert, K.W. A theoretical review and empirical investigation of employee trust in management. Public Adm. Q. 1992, 16, 265-284.

58. Schaubroeck, J.; Lam, S.S.; Peng, A.C. Cognition-based and affect-based trust as mediators of leader behavior influences on team performance. J. Appl. Psychol. 2011, 96, 863-871. [CrossRef] [PubMed]

59. Colquitt, J.A.; Scott, B.A.; LePine, J. Trust, trustworthiness, and trust propensity: A meta-analytic test of their unique relationships with risk taking and job performance. J. Appl. Psychol. 2007, 92, 909-927. [CrossRef] [PubMed]

60. Konczak, L.J.; Stelly, D.J.; Trusty, M.L. Defining and measuring empowering leader behaviors: Development of an upward feedback instrument. Educ. Psychol. Meas. 2000, 60, 301-313. [CrossRef]

61. Biemann, T.; Kearney, E.; Marggraf, K. Empowering leadership and managers' career perceptions: Examining effects at both the individual and the team level. Leadersh. Q. 2015, 26, 775-789. [CrossRef]

62. Park, J.G.; Kim, J.S.; Yoon, S.W.; Joo, B.K. The effects of empowering leadership on psychological well-being and job engagement: The mediating role of psychological capital. Leadersh. Organ. Dev. J. 2017, 38, 350-367. [CrossRef]

63. Tesluk, P.E.; Farr, J.L.; Klein, S.R. Influences of organizational culture and climate on individual creativity. J. Creat. Behav. 1997, 31, 27-41. [CrossRef]

64. Neves, P.; Eisenberger, R. Perceived organizational support and risk taking. J. Manag. Psychol. 2014, 29, 187-205. [CrossRef]

65. Rank, J.; Unger, B.N.; Gemunden, H.G. Preparedness for the future in project portfolio management: The roles of proactiveness, riskiness and willingness to cannibalize. Int. J. Proj. Manag. 2015, 33, 1730-1743. [CrossRef]

66. Chung-Yan, G.A.; Butler, A.M. Proactive personality in the context of job complexity. Can. J. Behav. Sci. Rev. Can. Sci. Comport. 2011, 43, 279-286. [CrossRef]

67. Campbell, D.J. Task complexity: A review and analysis. Acad. Manag. Rev. 1988, 13, 40-52. [CrossRef]

68. Campbell, D.J. Goal levels, complex tasks, and strategy development: A review and analysis. Hum. Perform. 1991, 4, 1-31. [CrossRef]

69. McGrath, J.E.; Berdahl, J.L.; Arrow, H. Traits, expectations, culture, and clout: The dynamics of diversity in work groups. In Diversity in Work Teams: Research Paradigms for A Changing Workplace; Jackson, S.E., Ruderman, M.N., Eds.; American Psychological Association: Washington, DC, USA, 1995; pp. 17-45.

70. Gong, T.; Choi, J.N. Effects of task complexity on creative customer behavior. Eur. J. Mark. 2016, 50, $1003-1023$. [CrossRef]

71. Maynard, D.C.; Hakel, M.D. Effects of objective and subjective task complexity on performance. Hum. Perform. 1997, 10, 303-330. [CrossRef]

72. Deci, E.L.; Ryan, R.M. Cognitive evaluation theory. In Intrinsic Motivation and Self-Determination in Human Behavior; Springer: Boston, MA, USA, 1985; pp. 43-85.

73. Cadwallader, S.; Jarvis, C.B.; Bitner, M.J.; Ostrom, A.L. Frontline employee motivation to participate in service innovation implementation. J. Acad. Mark. Sci. 2010, 38, 219-239. [CrossRef]

74. Edwards, J.R.; Lambert, L.S. Methods for integrating moderation and mediation: A general analytical framework using moderated path analysis. Psychol. Methods 2007, 12, 1-22. [CrossRef]

75. Brislin, R.W. Translation and content analysis of oral and written materials. In Handbook of Cross-Cultural Psychology; Triandis, H.C., Berry, J.W., Eds.; Allyn and Bacon: Boston, MA, USA, 1980; pp. 389-444.

76. Nunnally, J.C.; Bernstein, I.H. Psychological Theory; MacGraw-Hill: New York, NY, USA, 1994; pp. 131-147.

77. Podsakoff, P.M.; MacKenzie, S.B.; Lee, J.Y.; Podsakoff, N.P. Common method biases in behavioral research: A critical review of the literature and recommended remedies. J. Appl. Psychol. 2003, 88, 879-903. [CrossRef]

78. Schermelleh-Engel, K.; Moosbrugger, H.; Müller, H. Evaluating the fit of structural equation models: Tests of significance and descriptive goodness-of-fit measures. Methods Psychol. Res. Online 2003, 8, $23-74$.

79. Fornell, C.; Larcker, D.F. Evaluating structural equation models with unobservable variables and measurement error. J. Mark. Res. 1981, 18, 39-50. [CrossRef]

80. Bagozzi, R.P.; Yi, Y. On the evaluation of structural equation models. J. Acad. Mark. Sci. 1988, 16, 74-94. [CrossRef] 
81. Aiken, L.; West, S. Multiple Regression: Testing and Interpreting Interactions; Sage: Newbury Park, CA, USA, 1991.

82. Baron, R.M.; Kenny, D.A. The moderator-mediator variable distinction in social psychological research: Conceptual, strategic, and statistical considerations. J. Personal. Soc. Psychol. 1986, 51, 1173-1182. [CrossRef]

83. Preacher, K.J.; Hayes, A.F. SPSS and SAS procedures for estimating indirect effects in simple mediation models. Behav. Res. Methods Instrum. Comput. 2004, 36, 717-731. [CrossRef] [PubMed]

84. Hayes, A.F. PROCESS: A Versatile Computational Tool for Observed Variable Mediation, Moderation, and Conditional Process Modeling. In An Introduction to Mediation, Moderation, and Conditional Process Analysis: A Regression-based Approach; Guilford Press: New York, NY, USA, 2012.

85. Li, M.; Liu, W.; Han, Y.; Zhang, P. Linking empowering leadership and change-oriented organizational citizenship behavior. J. Organ. Chang. Manag. 2016, 29, 732-750. [CrossRef]

86. Berg, S.T.S.; Grimstad, A.; Škerlavaj, M.; Černe, M. Social and economic leader-member exchange and employee creative behavior: The role of employee willingness to take risks and emotional carrying capacity. Eur. Manag. J. 2017, 35, 676-687. [CrossRef]

87. García-Granero, A.; Llopis, Ó.; Fernández-Mesa, A.; Alegre, J. Unraveling the link between managerial risk-taking and innovation: The mediating role of a risk-taking climate. J. Bus. Res. 2015, 68, 1094-1104. [CrossRef]

88. Shen, W.; Hommel, B.; Yuan, Y.; Chang, L.; Zhang, W. Risk-taking and creativity: Convergent, but not divergent thinking is better in low-risk takers. Creat. Res. J. 2018, 30, 224-231. [CrossRef]

89. Fong, K.H.; Snape, E. Empowering leadership, psychological empowerment and employee Outcomes: Testing a multi-level mediating model. Br. J. Manag. 2015, 26, 126-138. [CrossRef]

90. Giorgetta, C.; Grecucci, A.; Zuanon, S.; Perini, L.; Balestrieri, M.; Bonini, N.; Sanfey, A.G.; Brambilla, P. Reduced risk-taking behavior as a trait feature of anxiety. Emotion 2012, 12, 1373-1383. [CrossRef]

91. Mishra, S.; Lalumière, M.L.; Williams, R.J. Gambling as a form of risk-taking: Individual differences in personality, risk-accepting attitudes, and behavioural preferences for risk. Personal. Individ. Differ. 2010, 49, 616-621. [CrossRef]

92. Choi, M. Employees' attitudes toward organizational change: A literature review. Hum. Resour. Manag. 2011, 50, 479-500. [CrossRef]

93. Huang, X.; Iun, J.; Liu, A.; Gong, Y. Does participative leadership enhance work performance by inducing empowerment or trust? The differential effects on managerial and non-managerial subordinates. J. Organ. Behav. 2010, 31, 122-143. [CrossRef]

94. Schilpzand, P.; Houston, L.; Cho, J. Not too tired to be proactive: Daily empowering leadership spurs next-morning employee proactivity as moderated by nightly sleep quality. Acad. Manag. J. 2018, 61, 2367-2387. [CrossRef]

95. Hackman, J.R.; Oldham, G.R. Motivation through the design of work: Test of a theory. Organ. Behav. Hum. Perform. 1976, 16, 250-279. [CrossRef]

96. Podsakoff, P.M.; MacKenzie, S.B.; Podsakoff, N.P. Sources of method bias in social science research and recommendations on how to control it. Annu. Rev. Psychol. 2012, 63, 539-569. [CrossRef] [PubMed]

97. Hogg, M.A.; Martin, R.; Epitropaki, O.; Mankad, A.; Svensson, A.; Weeden, K. Effective leadership in salient groups: Revisiting leader-member exchange theory from the perspective of the social identity theory of leadership. Personal. Soc. Psychol. Bull. 2005, 31, 991-1004. [CrossRef] [PubMed]

(C) 2020 by the authors. Licensee MDPI, Basel, Switzerland. This article is an open access article distributed under the terms and conditions of the Creative Commons Attribution (CC BY) license (http://creativecommons.org/licenses/by/4.0/). 